\title{
Clinical Pathology of Bartholin's Glands: A Review of the Literature
}

\author{
Min Y. Lee ${ }^{\mathrm{a}} \quad$ Amanda Dalpiaz $^{\mathrm{a}} \quad$ Richard Schwamb $^{\mathrm{a}}$ Yimei Miao $^{\mathrm{b}}$ \\ Wayne Waltzer ${ }^{\mathrm{b}} \quad$ Ali Khan $^{\mathrm{b}}$
}

aDepartment of Physiology and Biophysics; ${ }^{b}$ Department of Urology, SUNY School of Medicine, Stony Brook University, Stony Brook, NY., USA

\section{Key Words}

Bartholin's glands $\cdot$ Cysts $•$ Abscesses •

Vulval lubrication $\cdot$ Female reproductive system

\begin{abstract}
The Bartholin's glands are located symmetrically at the posterior region of the vaginal opening and play an important role in the female reproductive system. These two peasized glands are involved in mucus secretion and vaginal lubrication. Cyst formation in the glands is common and results from mucus build-up in gland ducts. It is important to monitor such cysts because they may occur in the form of carcinomas. Larger cysts and abscesses are found in the lower vestibular region and typically present with erythema and edema. Biopsy is an effective method for distinguishing between Bartholin's gland cysts and differential diagnosis. While smaller cysts may be asymptomatic and may be left untreated, larger cysts require medical attention. Several treatment options are available, including marsupialization and $\mathrm{CO}_{2}$ laser. Healing and recovery depend on the severity of infection and course of treatment.
\end{abstract}

Copyright $\odot 2014$ S. Karger AG, Basel

KARGER

Fax +4161306 1234

E-Mail karger@karger.ch

www.karger.com
(C) 2014 S. Karger AG, Basel

1015-9770/14/0081-0022\$38.00/0

Accessible online at:

www.karger.com/cur

\section{Introduction}

The Bartholin's glands are essential organs of the female reproductive system. The glands were first described in the 17th century by the Danish anatomist, Casper Bartholin. The organs' main function is to secrete mucus to ensure vaginal and vulval lubrication. The Bartholin's glands are prone to infections and abscess formation, which may result in vestibular pain and dyspareunia. The cause of these infections is associated with bacterial cultures, though other complications may cause Bartholin's cyst, abscess or malignancy. Bartholin's gland neoplasm may correlate to the individual's blood type antigen as studies have revealed diagnosis of Bartholin's carcinoma in patients with rare blood types [1]. This article will review the literature of Bartholin's anatomy, physiology, and pathology as well as treatment options for diseases of the Bartholin's glands.

\section{Anatomy, Physiology, and Embryology}

The Bartholin's glands, also called greater vestibular glands, are two pea-sized glands located at the posterior region of the vaginal opening. The glands have an oval shape with an average size of $0.5 \mathrm{~cm}$ and are located lateral to the bulbocavernosus muscle. The glands are homologous to the male bulbourethral or Cowper's glands. The glands are connected to ducts, approximately 2.5 $\mathrm{cm}$ in width, situated between the labia minora and the hymenal edge [2]. Through these ducts, the glands drain the mucus into the vaginal vestibule. The ducts open at the 4 and 8 o'clock position at the vaginal vestibule on each side of the vaginal opening [3]. Embryologically, the Bartholin's glands originate from the urogential sinus and therefore, utilize the external pudendal artery as a blood source [2]. The gland is innervated by the pudendal nerve. The lymphatic drainage of Bartholin's glands includes superficial inguinal and pelvic nodes. 
Table 1. Bacteriology of Bartholin's gland cyst and abscess

\begin{tabular}{ll}
\hline Bacterial agents: aerobes & Bacterial agents: anaerobes \\
\hline Brucella melitensis [6] & Bacteroides species \\
Chlamydia trachomatis [7] & Pasteurella bettii [14] \\
Escherichia coli [8] & Salmonella panama [15] \\
Hypermucoviscous Klebsiella pneumonia [9] & \\
Neisseria gonorrhea [7] & \\
Neisseria sicca [10] & \\
Pseudomonas aeruginosa [11] & \\
Staphylococcus aureus: Panton-Valentine & \\
Leucocidin production [12] & \\
Streptococcus species [13] & \\
\hline
\end{tabular}

\section{Pathophysiology}

Cysts are common complications of the Bartholin's gland, affecting the ductal region due to outlet blockage [2]. When the Bartholin's gland duct orifice becomes obstructed, the glands produce a build-up of mucus. This build-up leads to a cystic dilation of the duct and cyst formation. Infection of this cyst is likely to result in Bartholin's gland abscess. Duct cyst is not required for the development of abscess. The abscesses are almost three times more common than duct cysts [3]. Bartholin's abscess cultures often show polymicrobial infection.

Lesions in the Bartholin's gland can occur in the form of carcinomas, a rare type of gynecological tumor that accounts for 2-7\% of vulvar carcinomas. This type of vulvar growth is carefully monitored among postmenopausal women who are more prone to Bartholin's malignancy [4]. The median age at which Bartholin's gland cancer is diagnosed is 57 years old and carcinoma incidence is highest among women in their 60's. The 2 common types, adenocarcinoma and squamous cell carcinoma, account for $80-90 \%$ of primary cases. The remaining $10-20 \%$ of cases include transitional, adenoid-cystic or undifferentiated carcinomas [5]. Human papillomavirus is only related to squamous cell lesions. Benign tumors are rarer than carcinomas.

Large proportions of Bartholin's gland abscess are bacterial culture positive with Escherichia coli being a common pathogen (table 1). When determining antibacterial treatment options, it is essential to correlate the microbiological findings with their antibiogram [16].

\section{Clinical Manifestations and Symptoms}

Bartholin's duct cyst may be asymptomatic if the cyst is small and not inflamed. However, a small cyst may be observed by physicians as a small mass in the region of the Bartholin's gland. A painless mass may be present without surrounding cellulitis, while abscesses commonly present with cellulitis and lymphangitis. Larger cysts and abscess tend to cause severe vulvar pain and swelling such that the patient experiences difficulty in walking, sitting and engaging in sexual intercourse (dyspareunia). During examination, an abscess presents as a tender mass in the lower vestibular region surrounded by erythema and edema. When the abscess grows large enough to extend to the upper labia, it may
Table 2. Pathology of Bartholin's Glands

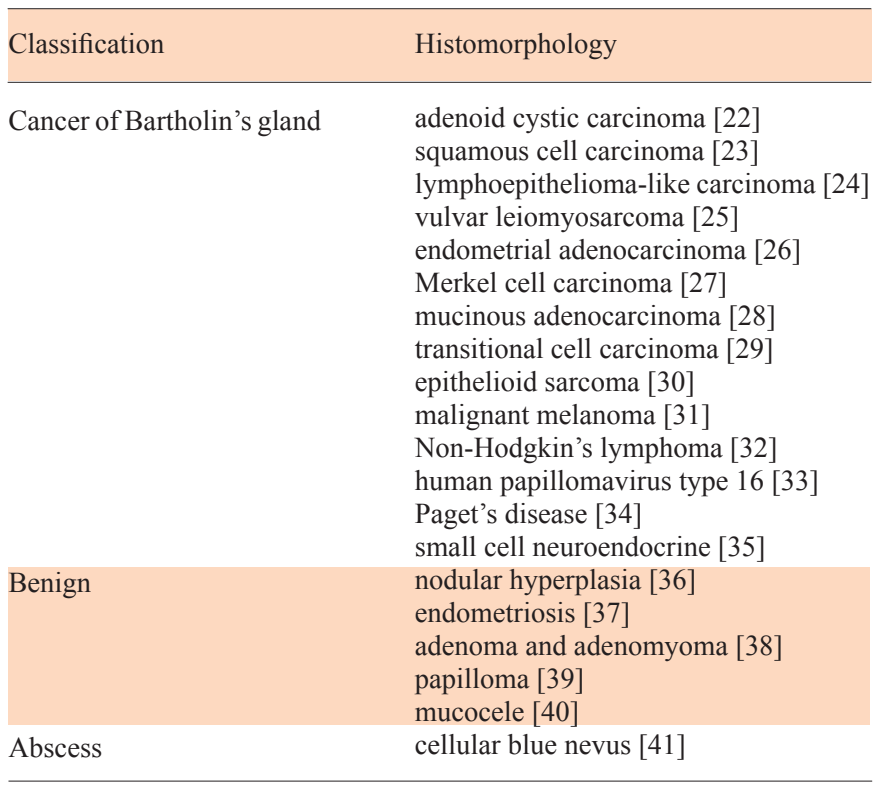

result in skin rupture and spontaneous drain [3]. The patient may experience a sudden relief of pain after a discharge, highly suggesting presence of spontaneous rupture. Cysts can present in form of inguinal hernia [17].

In neonate, Bartholin's duct cyst associated with hydroureteronephrosis and contralateral renal cyst can cause urinary retention [18]. In the case of Bartholin's gland cancer, painless mass is also present in the vulva-region. Mass fixated to the underlying tissue is often suspected for malignancy. First detection of sentinel node may lead to diagnosis of adenocarcinoma of Bartholin's gland [19].

\section{Diagnosis}

Diagnosis of Bartholin's gland carcinoma is established upon histological examination. Women over the age of 40 are recommended to undergo drainage and biopsy to eliminate possible occurrence of carcinoma. Due to the rarity of Bartholin's cancer, a biopsy is recommended over excision [20]. In cases where Bartholin's cancer is suspected, diagnostic criteria is as follows. The tumor must be primarily located in the labia, the surrounding skin must remain undamaged, and there must be at least a small amount of glandular epithelium present. When Bartholin gland carcinomas are present, metastatic disease is likely due to the vulva's extensive vascular and lymphatic network [2].

\section{Differential Diagnosis}

Several labia and vaginal lesions can imitate Bartholin's gland diseases. In such situations, differential diagnosis should be considered for the abscess or mass. Differential diagnosis include different types of cysts (inclusion, Gartner, Skene's, sebaceous, vestibular mucosa, canal of Nuck), leiomyomas fibroma, hernia, hidradenoma, hematomas, lipomas, endometriosis, syringoma, 
accessory breast tissue, folliculitis, urethral diverticula, hidradenitis suppurativa, chancroid, gonorrhea, syphilis, vaginitis, warts or Bartholin's gland cyst, abscess or cancer [21] (table 2).

\section{Radiology}

Magnetic resonance imaging and computed tomography may be utilized to examine large Bartholin's duct cysts in addition to a physical examination [42]. Asymptomatic cysts may also be examined through magnetic resonance imaging scans [43]. High definition ultrasound imaging is also used to reveal presence of Bartholin's cyst [44].

\section{Treatment}

Asymptomatic Bartholin's gland cysts can be left untreated without detrimental consequences. Simple and quick method of providing relief for a patient is an incision and drainage of the infected area followed by a suture closure; however, this method is prone to recurrence of cyst or abscess formation[45]. Sitz baths are recommended for abscesses that tend to spontaneously rupture.

A "Word" catheter is a common, more conservative method for treating Bartholin's cyst and abscess that helps prevent recurrence. The catheter consists of an inflatable balloon tip filled with saline solution. The treatment requires a small incision to be made at the infected area and a Word catheter balloon to be placed inside the cyst or abscess cavity. The catheter is left inside for 4-6 weeks to ensure epithelialization and Sitz baths are recommended to aid the healing process. Catheter treatment is not advised for treatment of deep cysts and abscesses [21]. Foley catheter and Jacobi ring are also methods of fistulization that may be used [46].

Marsupialization is an alternative treatment method for Bartholin's glands cysts that allows for a less invasive method of cyst drainage. Small hemostats are used to clasp the cyst and a vertical incision about $1.5-3 \mathrm{~cm}$ long is made to drain the infected gland cavity. Saline solution can be used to moisten the area followed by eversion of the cyst wall with absorbable suture. In the presence of an abscess, marsupialization should not be performed. Complications such as hematoma, dyspareunia and infection may occur [3].
Due to disadvantage of recurrence, scarring, persistent drainage, and hemorrhage associated with commonly used treatments, $\mathrm{CO}_{2}$ laser serves as an advantageous method of avoiding such results. Incision on the cyst is made with $\mathrm{CO}_{2}$ laser and the wall is vaporized from the inside. In reported cases, the cysts healed with no scar formation and minimal incidence of recurrence [47].

Other methods of treating Bartholin's gland cyst and abscess include silver nitrate gland ablation, laser, needle aspiration with or without alcohol sclerotherapy and gland excision [48]. When treating patients of age 40 or older, careful consideration should be taken in regards to excision of the gland. Medication and antibiotics are used to treat Bartholin's abscesses as the infection is mostly caused by pathogens. Antibiotic therapy may not be necessary for healthy women with uncomplicated abscesses. Antibiotic therapies include Ceftriaxone, Ciprofloxacin, Doxycycline and Azithromycin. This treatment option should be restricted to women who have high risk of complicated infection such as recurrence, pregnancy, immunosuppression, MRSA risk, widespread surrounding cellulitis and gonorrhea or chlamydia infection. Topical or local anesthetics such as lidocaine and bupivacaine are also used to treat abscesses.

Treatment of Bartholin's carcinomas may vary between surgical methods, vulvectomy, or radiotherapy [49]. Hyperbaric oxygen therapy following radical vulvectomy promotes wound healing [50]. Primary adenoid cystic carcinoma is a rare malignancy of Bartholin's cancer. Patients with the cancer can undergo adjuvant external beam radiation or hemivulvectomy [51]. Early stage I of Bartholin's carcinoma can be approached with lymphadenectomy [52].

\section{Conclusion}

The Bartholin's glands make up a crucial part of the female reproductive system by allowing for vaginal lubrication. The blockage of the glands' ducts often leads to formation of a cyst and consequently an abscess may develop. Although small cysts may be asymptomatic and can be left untreated, large cysts and abscess require attention and medical treatment. Various methods are available as treatment methods and healing can depend on level of infection, treatment method, and patient's condition.

\section{References}

1 Sosnik H, Sosnik K, Halon A: The pathomorphology of Bartholin's gland. Analysis of surgical data. Pol J Pathol 2007;58:99-103.

2 Antvorskov JC, Josefsen K, Engkilde K, Funda DP, Buschard K: Dietary gluten and the development of type 1 diabetes. Diabetologia 2014;75:1770-1780.

3 Omole F, Simmons BJ, Hacker Y: Management of Bartholin's duct cyst and gland abscess. Am Fam Physician 2003;68:135-140.
4 Schwarzlos G, Bolz M, Muller H: Primary carcinoma of Bartholin's glands with HPV 18 detection. Zentralbl Gynakol 1997;119:133135.

5 Felix JC, Cote RJ, Kramer EE, Saigo P, Goldman GH: Carcinomas of Bartholin's gland. Histogenesis and the etiological role of human papillomavirus. Am J Pathol 1993;142: 925-933.
6 Peled N, David Y, Yagupsky P: Bartholin's gland abscess caused by Brucella melitensis. J Clin Microbiol 2004;42:917-918.

7 Bleker OP, Smalbraak DJ, Schutte MF: Bartholin's abscess: the role of Chlamydia trachomatis. Genitourin Med 1990;66:24-25.

8 Tanaka K, Mikamo H, Ninomiya M, Tamaya T, Izumi K, Ito K, Yamaoka K, Watanabe K: Microbiology of Bartholin's gland abscess in Japan. J Clin Microbiol 2005;43:4258-4261. 
9 Pinsky BA, Baron EJ, Janda JM, Banaei N: Bartholin's abscess caused by hypermucoviscous Klebsiella pneumoniae. J Med Microbiol 2009;58:671-673.

10 Berger SA, Gorea A, Peyser MR, Edberg SC: Bartholin's gland abscess caused by Neisseria sicca. J Clin Microbiol 1988;26:1589.

11 Touzot F, De Pontual L, Letamendia-Richard E, Fayad F, Nathanson M, Lachassinne E, Gaudelus J: Acute bartholinitis caused by Pseudomonas aeruginosa in an 18-month-old infant. Arch Pediatr 2004;11:1070-1072.

12 Jung N, Lehmann C, Hellmann M, Seifert H, Valter MM, Hallek M, Fätkenheuer G, Kochanek M: Necrotizing pneumonia caused by Panton-Valentine leucocidin-producing Staphylococcus aureus originating from a Bartholin's abscess. Infect Dis Obstet Gynecol 2008;2008:491401.

13 Parvathi S, Imara AS, Thoduka TG: Bartholinitis caused by Streptococcus pneumoniae: case report and review of literature. Indian J Pathol Microbiol 2009;52:265-266.

14 Sneath PH, Stevens M: Actinobacillus rossii sp. nov., Actinobacillus seminis sp. nov. nom. rev., Pasteurella bettii sp. nov., Pasteurella lymphangitidis sp. nov., Pasteurella mairi sp. nov., and Pasteurella trehalosi sp. nov. Int J Syst Bacteriol 1990;40:148-153.

15 Cummins AJ, Atia WA: Bartholin's abscess complicating food poisoning with Salmonella panama: a case report. Genitourin Med 1994;70:46-48.

16 Kessous R, Aricha-Tamir B, Sheizaf B, Steiner N, Moran-Gilad J, Weintraub AY: Clinical and microbiological characteristics of Bartholin gland abscesses. Obstet Gynecol 2013;122:794-799.

17 Altstiel T, Coster R: Bartholin cyst presenting as inguinal hernia. S D J Med 1993;46:7-8.

18 Cevik M, Savas M, Guldur ME, Boleken ME: Urinary retention as the presentation of Bartholin's duct cyst in a neonate. J Pediatr Adolesc Gynecol 2012;25:e65-67.

19 Balepa L, Baeyens L, Nemec E, Verhas M: First detection of sentinel node in adenocarcinoma of Bartholin's gland. J Gynecol Obstet Biol Reprod (Paris) 2004;33:649-651.

20 Mayeaux EJ Jr, Cooper D: Vulvar procedures: biopsy, bartholin abscess treatment, and condyloma treatment. Obstet Gynecol Clin North Am 2013;40:759-772.

21 Koc O, Sengul N, Gurel S: Perineal leiomyoma mimicking complex Bartholin mass. Int Urogynecol J 2010;21:495-497.

22 Hwang TL, Hung YC, Chang HW: Adenoid cystic carcinoma of Bartholin's gland. Taiwan J Obstet Gynecol 2012;51:119-120.

23 Ng SM, Nunns D, Lamb M: Bartholin's gland squamous cell carcinoma. J Obstet Gynaecol 2012;32:318-319.
24 Kacerovska D, Nemcova J, Petrik R, Michal M, Kazakov DV: Lymphoepithelioma-like carcinoma of the Bartholin gland. Am J Dermatopathol 2008;30:586-589.

25 Gonzalez-Bugatto F, Anon-Requena MJ, Lopez-Guerrero MA, Baez-Perea JM, Bartha JL, Hervias-Vivancos B: Vulvar leiomyosarcoma in Bartholin's gland area: a case report and literature review. Arch Gynecol Obstet 2009;279:171-174.

26 Ray K, Rocconi RP, Novak L, Straughn JM Jr: Recurrence of endometrial adenocarcinoma in a prior Bartholin's cyst marsupialization incision. Gynecol Oncol 2006;103:749-751.

27 Khoury-Collado F, Elliott KS, Lee YC, Chen PC, Abulafia O: Merkel cell carcinoma of the Bartholin's gland. Gynecol Oncol 2005; 97:928-931.

28 Ohno T, Nakano T, Abe A, Sano T, Niibe Y, Oka K: Mucinous adenocarcinoma of Bartholin gland treated with radiation therapy: a case report. Jpn J Clin Oncol 2001;31:226230.

29 Fujiwaki R, Takahashi K, Nishiki Y, Ryuko K, Kitao M: Rare case of transitional cell carcinoma originating in Bartholin's gland duct. Gynecol Obstet Invest 1995;40:278-280.

30 Konefka T, Senkus E, Emerich J, Dudziak M: Epithelioid sarcoma of the Bartholin's gland primarily diagnosed as vulvar carcinoma. Gynecol Oncol 1994;54:393-395.

31 Finan MA, Barre G: Bartholin's gland carcinoma, malignant melanoma and other rare tumours of the vulva. Best Pract Res Clin Obstet Gynaecol 2003;17:609-633.

32 Tjalma WA, Van de Velde AL, Schroyens WA: Primary non-Hodgkin's lymphoma in Bartholin's gland. Gynecol Oncol 2002; 87:308-309.

33 Sheard JD, Vijayanand R, Herrington CS, Giannoudis A, Shaw G: High-grade squamous intraepithelial neoplasia in a Bartholin's gland cyst associated with HPV 16 infection. Histopathology 2000;37:87-88.

34 Hastrup N, Andersen ES: Adenocarcinoma of Bartholin's gland associated with extramammary Paget's disease of the vulva. Acta Obstet Gynecol Scand 1988;67:375-377.

35 Jones MA, Mann EW, Caldwell CL, Tarraza HM, Dickersin GR, Young RH: Small cell neuroendocrine carcinoma of Bartholin's gland. Am J Clin Pathol 1990;94:439-442.

36 Hjorto SP, Pehrson C, Gernow A: Nodular hyperplasia of the Bartholin gland. Ugeskr Laeger 2010;172:969-970.

37 Gocmen A, Inaloz HS, Sari I, Inaloz SS: Endometriosis in the Bartholin gland. Eur J Obstet Gynecol Reprod Biol 2004;114:110 111.
38 Koenig C, Tavassoli FA: Nodular hyperplasia, adenoma, and adenomyoma of Bartholin's gland. Int J Gynecol Pathol 1998;17: 289-294.

39 Enghardt M, Valente PT, Day DH: Papilloma of Bartholin's gland duct cyst: first report of a case. Int J Gynecol Pathol 1993;12:86-92.

40 Freedman SR, Goldman RL: Mucocele-like changes in Bartholin's glands. Hum Pathol 1978;9:111-114

41 Yamazhan M, Ertas IE, Kandiloglu G, Ozeren M: Cellular blue nevus of the vulva mimicking Bartholin's gland abscess in a 15-year-old girl: a case report. Arch Gynecol Obstet 2012;285:1009-1011.

42 Kozawa E, Irisawa M, Heshiki A, Kimura F, Shimizu Y: MR findings of a giant Bartholin's duct cyst. Magn Reson Med Sci 2008; 7:101-103.

43 Berger MB, Betschart C, Khandwala N, DeLancey JO, Haefner HK: Incidental bartholin gland cysts identified on pelvic magnetic resonance imaging. Obstet Gynecol 2012 120:798-802.

44 Eppel W, Frigo P, Worda C, Bettelheim D: Ultrasound imaging of Bartholin's cysts. Gynecol Obstet Invest 2000;49:179-182.

45 Hill DA, Lense JJ: Office management of Bartholin gland cysts and abscesses. Am Fam Physician 1998;57:1611-1616,1619-1620.

46 Gennis P, Li SF, Provataris J, Shahabuddin S, Schachtel A, Lee E, Bobby P: Jacobi ring catheter treatment of Bartholin's abscesses. Am J Emerg Med 2005;23:414-415.

47 Lashgari M, Keene M: Excision of Bartholin duct cysts using the $\mathrm{CO} 2$ laser. Obstet Gynecol 1986;67:735-737.

48 Wechter ME, Wu JM, Marzano D, Haefner $\mathrm{H}$ : Management of Bartholin duct cysts and abscesses: a systematic review. Obstet Gynecol Surv 2009;64:395-404.

49 Duun S: Adenoid cystic carcinoma of Bartholin's gland--a review of the literature and report of a patient. Acta Obstet Gynecol Scand 1995;74:78-80.

50 Reedy MB, Capen CV, Baker DP, Petersen WG, Kuehl TJ: Hyperbaric oxygen therapy following radical vulvectomy: an adjunctive therapy to improve wound healing. Gynecol Oncol 1994;53:13-16.

51 Hsu ST, Wang RC, Lu CH, Ke YM, Chen YT, Chou MM, Ho ES: Report of two cases of adenoid cystic carcinoma of Bartholin's gland and review of literature. Taiwan J Obstet Gynecol 2013;52:113-116.

52 Kraemer B, Guengoer E, Solomayer EF, Wallwiener D, Hornung R: Stage I carcinoma of the Bartholin's gland managed with the detection of inguinal and pelvic sentinel lymph node. Gynecol Oncol 2009;114:373-374. 